\title{
Heavy Metals in Organs and Tissues of Silver X Bigheads Carp Hybrid as Indices of Anthropogenic Pressure in Areas with a High Level of Urbanization
}

\author{
A.A. Makarenko ${ }^{1, a^{*}}$, P.G. Shevchenko ${ }^{1, b}$, I.S. Kononenko, \\ V.M. Kondratyk ${ }^{1, d}$, D.S. Khrystenko ${ }^{1, e}$, V.V. Grubinko ${ }^{2, f}$ \\ ${ }^{1}$ National University of Life and Environmental Sciences of Ukraine, Kyiv, Ukraine \\ ${ }^{2}$ Ternopil National Pedagogical University named after V. Hnatyuk, Ternopil, Ukraine \\ aalmakarenko912@gmail.com, bshevchenko.petr@gmail.com, ckononenko_irina88@ukr.net, \\ vadkondratyk@ukr.net, edskhrist@gmail.com, fv.grubinko@gmail.com
}

Keywords: pond, hybrid silver x bighead carp, gills, liver, muscles.

\begin{abstract}
The growth of man-caused load on natural objects, including surface waters, gave impetus to the studying for issue of water pollution in Ukraine by various pollutants. Especially relevant for us are the studies of fishery reservoirs as a direct environment for growing quality aquaculture products. Among the toxic compounds contained in reservoirs, one of the first places is occupied by heavy metals. On the one hand, heavy metals, as pollutants in natural waters, pose a great danger because even in relatively small concentrations they can adversely affect aquatic organisms. On the other hand, in microquantities most heavy metals (except mercury, cadmium and lead) are a natural and even essential component of living cells of aquatic organisms, including fish $[17,19]$.

$\mathrm{Zn}, \mathrm{Mn}, \mathrm{Fe}, \mathrm{Cu}, \mathrm{Pb}, \mathrm{Co}, \mathrm{Ni}, \mathrm{Cd}$ in the organs and tissues of the bighead carp hybrid form, which was cultivated in ponds from highly urbanized territory, are distributed heterogeneously and their level of content depends not only on the physical and chemical characteristics of the aquatic environment or this heavy metals biochemical activities force in fish organisms, but also on functional features of concrete organs and tissues of the latter. Results of our investigations showed that above mentioned heavy metals were characterised by high levels of content in the organs and tissues of hybrid silver $x$ bighead carp. Highest content in organism of hybrid are lead, cobalt, and cadmium. Highest concentration of heavy metals in our investigations was recorded in gills, because it is the first defence line of fish organism from environmental pollutants.
\end{abstract}

\section{Introduction}

Fish ecology and development of fish productivity in water bodies appear to be the urgent tasks of modern scientific research. The productivity of different fish species in freshwater ecosystems depends on environmental conditions. Fish, like any other aquatic organisms, respond sharply to the quality of aquatic environment. In addition, they are an important link in the unremitting movement of micro- and macronutrients - metals that are essential elements for normal development of aquatic organisms in different water bodies. Such elements as $\mathrm{Zn}, \mathrm{Mn}, \mathrm{Fe}, \mathrm{Cu}, \mathrm{Pb}$, $\mathrm{Co}, \mathrm{Ni}, \mathrm{Cd}$ play a significant role in implementation of numerous physiological and biochemical processes (due to the influence on activity of enzymes and enzymatic complexes). Heavy metals accumulate in fish organs and tissues depending on geochemical environmental conditions, nature of water bodies, functional state of fish organism, and type of food chain $[5,16,20]$.

One of the urgent tasks of modern ichthyological and ecological research is the analysis of the accumulation peculiarities of heavy metals in the organs and tissues of freshwater fish, which was grown in aquaculture, from areas with a high level of urbanization [7]. The content level and distribution specifics of heavy metals in fish organisms directly determine both the fish productivity of the water body and the safety of aquaculture products for the final consumer. Due to the high biological activity, heavy metals, depending on the concentration and time of exposure, as well as many other factors, can be characterized by both positive and negative effects on hydrobionts in 
general, and fish in particular. Such heavy metals as $\mathrm{Zn}, \mathrm{Mn}, \mathrm{Fe}, \mathrm{Cu}, \mathrm{Pb}, \mathrm{Co}, \mathrm{Ni}, \mathrm{Cd}$ are the most common in the aquatic environment and in fish organisms with a high biological activity. They are involved in all anabolism and catabolism processes, in particular, being a part of enzymes. Their content and distribution in fish organs and tissues depends not only on geochemical or hydrochemical factors, but also is species-specific. Accordingly, they are directly affected both by the species specificity and its age, which largely determines the general functional state of the organism and its place in the trophic chain of a particular ecotope. Thus, the process of accumulation of heavy metals is an obligate state of hydrobiont, necessary to maintain their normal functions through the synthesis of organometallic compounds (enzymes, hormones, vitamins, etc.) $[3,12,20]$. However, the concentrations exceeding and ratios imbalance of the above-mentioned heavy metals in the environment and fish organisms could led to a pathological process. The latter act on all links of the food chain are potentially dangerous to humans due to the ability of heavy metals to accumulate and synergy. This problem is especially relevant to aquaculture in the areas with high urbanization level. Pond-based aquaculture is the riskiest in terms of heavy metals content in the final products, primarily due to the significant complexity of removing the latter from the aquatic environment. At the same time, it is the most common type of management in the world in general and Ukraine in particular. Its products are able to provide humanity with relatively cheap and high-quality animal protein $[8,9,13,15,18]$.

Taking that in mind, it is necessary to mention that the urbanization processes are directly and rapidly developing, immediately interrelated with the anthropogenic load on water bodies. In turn, this contributes to the constant flow and formation of heavy metals ligands in the aquatic environment and in fish, having a complex destructive effect on the ecotope. The toxic effect of the heavy metals is irreversible and, for the most part, has a mutagenic effect. Therefore, determining the distribution and concentration of heavy metals in fish organs and tissues is very important for solving problems of quality control of fish products, monitoring the biological and chemical state of the aquatic environment $[4,6,10,13]$.

Today in natural and artificial reservoirs of Ukraine there are no pure lines of silver and bighead carp, and in fishery practice use their hybrid, which was chosen by us for research. The hybrid of silver $\mathrm{x}$ bighead carp, compared to the parent forms, is more stable at relatively low temperatures and has a rapid rate of weight gain during the growing period, which makes it more economical to growing.

The aim of our investigation is to determine the general tendencies of heavy metals (zinc, manganese, iron, copper, lead, cobalt, nickel, cadmium) content and distribution in organs and tissues of 3 main ((H1), second summers (H1+) and (H2)) age groups of hybrid silver $\mathrm{x}$ bighead carp from experimental ponds, which were used for the analysis of anthropogenic pressure in areas with a high urbanization level.

\section{Materials and Methods}

The investigation was performed during spring and autumn seasons from 2017 to 2019 in 3 state scientific-experimental enterprises that used ponds. All of them were placed in the Kyiv region - areas with the highest urbanization level in Ukraine. Regarding these factors, we have chosen "Training, Research and Production Laboratory of Fish Farming" of the National University of Life and Environmental Sciences (village Nemyshayevo - lowest level of anthropogenic pressure), "Bila Tserkva Experimental Hydrobiological Station" of the Institute of Hydrobiology of the National Academy of Sciences (small city Bila Tserkva - middle level of anthropogenic pressure) and "Nyvka" of the Institute of Fisheries of the National Academy of Agrarian Sciences (large city Kyiv - highest level of anthropogenic pressure).

Collection of ichthyological material was carried out in daylight throughout the water area of the studied reservoirs during stocking (spring) and catching (autumn) ponds, using a set of shutter grids with a mesh size of 30 to $100 \mathrm{~mm}$.

Heavy metals in fish organs and tissues were analysed in 2 replicates for 5 fish specimen, in 3 main $((\mathrm{H} 1),(\mathrm{H} 1+)$ and $(\mathrm{H} 2))$ age groups of hybrid silver $x$ bighead carp, from all of above 
mentioned enterprises. Consequently, we get totally 270 samples (of liver, white muscle and gills from 90 fish). Each of them was weighing $0.3 \mathrm{~g}$. Sampling and sample preparation were carried out due to generally accepted methods (All Union State standard 26929-94, 1994) [1].

Biomass samples were mineralized by the acid digestion method. Ten $\mathrm{ml}$ of $\mathrm{HNO}_{3}$ (extra pure grade) were added to the sample and heated at $105^{\circ} \mathrm{C}$ for 4 hours. Then $3 \mathrm{ml}$ of $30 \% \mathrm{H}_{2} \mathrm{O}_{2}$ were added to the mixture after cooling, and heated for 1 hour. The heavy metals content in the obtained nitrate elucidations were determined by atomic absorption spectrophotometry on a C-115 spectrophotometer at appropriate wave lengths that corresponded to the maximum absorption of each of the investigated metals (All Union State standard 30178-96, 2010) [2].

Using of common methods provided sufficient representativeness of experimental data for statistical analysis, which was performed using the application program Statistica 10.0.

\section{Results and Discussion}

The research and data analysis provided an opportunity to determine the accumulation patterns (content) of heavy metals ( $\mathrm{Zn}, \mathrm{Mn}, \mathrm{Fe}, \mathrm{Cu}, \mathrm{Pb}, \mathrm{Co}, \mathrm{Ni}, \mathrm{Cd}$ ) and the peculiarities of their distribution in the organs and tissues of hybrid silver $x$ bighead carp form as an indices of anthropogenic pressure in areas with a high urbanization level. The results of our investigations are given in tables $1,2,3$.

Table 1. Heavy metals content and distribution in the organs and tissues of (H1) age group of hybrid silver $x$ bighead carp form, harvested in the wintering pond in the spring of 2017 \& 2018, $\mathrm{M} \pm \mathrm{m}, \mu \mathrm{g} / \mathrm{kg}$ of raw weight

\begin{tabular}{|c|c|c|c|c|c|c|c|}
\hline $\begin{array}{l}\text { Heavy } \\
\text { metals }\end{array}$ & $\begin{array}{c}\text { Max } \\
\text { admissible }\end{array}$ & Liver & Gills & Muscles & Liver & Gills & Muscles \\
\hline 1 & 2 & 3 & 4 & 5 & 6 & 7 & 8 \\
\hline \multicolumn{5}{|c|}{ Spring 2017} & \multicolumn{3}{|c|}{ Spring 2018} \\
\hline \multicolumn{8}{|c|}{ Pond of "Nyvka" } \\
\hline & & \multicolumn{3}{|c|}{$\mathrm{n}=5$} & \multicolumn{3}{|c|}{$\mathrm{n}=5$} \\
\hline $\mathrm{Zn}$ & 40,0 & $16,26 \pm 0,30$ & $21,82 \pm 0,39$ & $14,08 \pm 1,08$ & $22,52 \pm 0,71$ & $29,32 \pm 0,53$ & $11,24 \pm 0,62$ \\
\hline $\mathrm{Mn}$ & 2,0 & $3,66 \pm 0,22$ & $6,06 \pm 0,19$ & $4,14 \pm 0,32$ & $2,96 \pm 0,21$ & $6,08 \pm 0,11$ & $3,98 \pm 0,08$ \\
\hline $\mathrm{Fe}$ & 30 & $33,12 \pm 0,91$ & $23,46 \pm 0,18$ & $23,44 \pm 4,60$ & $37,32 \pm 1,23$ & $29,94 \pm 0,92$ & $18,92 \pm 0,61$ \\
\hline $\mathrm{Cu}$ & 10 & $6,56 \pm 0,86$ & $6,96 \pm 0,47$ & $5,46 \pm 0,83$ & $10,0 \pm 0,63$ & $13,56 \pm 0,53$ & $11,22 \pm 0,27$ \\
\hline $\mathrm{Pb}$ & 1,0 & $14,92 \pm 0,30$ & $13,76 \pm 0,50$ & $11,42 \pm 1,64$ & $7,28 \pm 0,66$ & $17,0 \pm 1,45$ & $16,0 \pm 0,88$ \\
\hline Co & 0,08 & $0,36 \pm 0,02$ & $0,67 \pm 0,02$ & $0,57 \pm 0,09$ & $1,39 \pm 0,09$ & $2,05 \pm 0,15$ & $1,41 \pm 0,10$ \\
\hline $\mathrm{Ni}$ & 0,5 & $3,40 \pm 0,17$ & $3,53 \pm 0,27$ & $2,83 \pm 0,21$ & $2,90 \pm 0,09$ & $3,53 \pm 0,15$ & $3,19 \pm 0,12$ \\
\hline $\mathrm{Cd}$ & 0,2 & $2,32 \pm 0,21$ & $3,20 \pm 0,18$ & $2,74 \pm 0,27$ & $3,18 \pm 0,18$ & $3,66 \pm 0,12$ & $3,24 \pm 0,06$ \\
\hline \multicolumn{8}{|c|}{ Pond of "Bila Tserkva Experimental Hydrobiological Station" } \\
\hline & & \multicolumn{3}{|c|}{$n=5$} & \multicolumn{3}{|c|}{$\mathrm{n}=5$} \\
\hline $\mathrm{Zn}$ & 40,0 & $26,56 \pm 0,77$ & $33,56 \pm 1,79$ & $15,30 \pm 1,28$ & $22,96 \pm 2,15$ & $34,20 \pm 1,53$ & $15,14 \pm 1,65$ \\
\hline $\mathrm{Mn}$ & 2,0 & $4,04 \pm 0,11$ & $4,63 \pm 0,47$ & $4,62 \pm 0,34$ & $4,12 \pm 0,73$ & $6,32 \pm 0,66$ & $4,50 \pm 0,49$ \\
\hline $\mathrm{Fe}$ & 30 & $45,30 \pm 1,78$ & $19,27 \pm 0,52$ & $13,90 \pm 0,25$ & $44,14 \pm 4,12$ & $17,18 \pm 1,45$ & $15,86 \pm 1,60$ \\
\hline $\mathrm{Cu}$ & 10 & $10,86 \pm 0,39$ & $9,38 \pm 0,56$ & $9,30 \pm 0,78$ & $8,22 \pm 0,76$ & $8,72 \pm 0,88$ & $7,12 \pm 1,62$ \\
\hline $\mathrm{Pb}$ & 1,0 & $10,82 \pm 1,15$ & $13,90 \pm 0,88$ & $9,64 \pm 0,26$ & $10,96 \pm 1,84$ & $9,88 \pm 1,34$ & $10,28 \pm 1,36$ \\
\hline Co & 0,08 & $1,14 \pm 0,08$ & $0,99 \pm 0,04$ & $0,91 \pm 0,05$ & $0,83 \pm 0,16$ & $0,79 \pm 0,12$ & $0,74 \pm 0,10$ \\
\hline $\mathrm{Ni}$ & 0,5 & $4,09 \pm 0,12$ & $3,84 \pm 0,14$ & $4,05 \pm 0,17$ & $3,87 \pm 0,34$ & $3,57 \pm 0,36$ & $4,09 \pm 0,14$ \\
\hline $\mathrm{Cd}$ & 0,2 & $3,04 \pm 0,05$ & $3,26 \pm 0,05$ & $3,30 \pm 0,04$ & $3,08 \pm 0,10$ & $3,26 \pm 0,15$ & $3,36 \pm 0,25$ \\
\hline \multicolumn{8}{|c|}{ Pond of "Training, Research and Production Laboratory of Fish Farming" } \\
\hline & & \multicolumn{3}{|c|}{$\mathrm{n}=5$} & \multicolumn{3}{|c|}{$\mathrm{n}=5$} \\
\hline $\mathrm{Zn}$ & 40,0 & $27,42 \pm 1,09$ & $31,74 \pm 0,10$ & $17,16 \pm 1,13$ & $28,62 \pm 0,65$ & $32,30 \pm 0,98$ & $11,38 \pm 0,50$ \\
\hline $\mathrm{Mn}$ & 2,0 & $4,90 \pm 0,28$ & $7,98 \pm 0,47$ & $5,14 \pm 0,43$ & $3,56 \pm 0,16$ & $5,48 \pm 0,23$ & $4,72 \pm 0,36$ \\
\hline $\mathrm{Fe}$ & 30 & $37,18 \pm 0,56$ & $27,18 \pm 1,04$ & $17,88 \pm 0,68$ & $42,24 \pm 0,65$ & $26,04 \pm 1,08$ & $18,86 \pm 0,45$ \\
\hline $\mathrm{Cu}$ & 10 & $12,54 \pm 0,82$ & $17,58 \pm 0,59$ & $13,32 \pm 0,80$ & $18,16 \pm 0,72$ & $15,96 \pm 0,65$ & $18,54 \pm 0,50$ \\
\hline $\mathrm{Pb}$ & 1,0 & $7,94 \pm 0,40$ & $18,54 \pm 0,54$ & $13,14 \pm 0,72$ & $16,42 \pm 1,32$ & $21,20 \pm 1,04$ & $19,44 \pm 0,94$ \\
\hline Co & 0,08 & $1,20 \pm 0,03$ & $1,96 \pm 0,09$ & $1,69 \pm 0,05$ & $1,97 \pm 0,09$ & $2,04 \pm 0,12$ & $1,68 \pm 0,21$ \\
\hline $\mathrm{Ni}$ & 0,5 & $2,96 \pm 0,10$ & $3,46 \pm 0,17$ & $2,91 \pm 0,12$ & $3,93 \pm 0,13$ & $4,47 \pm 0,04$ & $4,43 \pm 0,05$ \\
\hline $\mathrm{Cd}$ & 0,2 & $4,12 \pm 0,29$ & $4,84 \pm 0,24$ & $2,70 \pm 0,21$ & $3,44 \pm 0,11$ & $4,38 \pm 0,15$ & $3,30 \pm 0,03$ \\
\hline
\end{tabular}


Table 2. Heavy metals content and distribution in the organs and tissues of $(\mathrm{H} 1+)$ age group of hybrid silver $x$ bighead carp form, harvested in the forage pond in the autumn of $2017 \& 2018, M \pm m, n=5, \mu \mathrm{g} / \mathrm{kg}$ of raw weight

\begin{tabular}{|c|c|c|c|c|c|c|c|}
\hline $\begin{array}{l}\text { Heavy } \\
\text { metals }\end{array}$ & $\begin{array}{c}\text { Max } \\
\text { admissible }\end{array}$ & Liver & Gills & Muscles & Liver & Gills & Muscles \\
\hline 1 & 2 & 3 & 4 & 5 & 6 & 7 & 8 \\
\hline & & \multicolumn{3}{|c|}{ Autumn 2017} & \multicolumn{3}{|c|}{ Autumn 2018} \\
\hline \multicolumn{8}{|c|}{ Pond of "Nyvka" } \\
\hline & & \multicolumn{3}{|c|}{$\mathrm{n}=5$} & \multicolumn{3}{|c|}{$\mathrm{n}=5$} \\
\hline $\mathrm{Zn}$ & 40,0 & $27,14 \pm 0,39$ & $33,30 \pm 0,10$ & $15,02 \pm 0,42$ & $45,98 \pm 1,59$ & $46,36 \pm 1,38$ & $25,02 \pm 0,52$ \\
\hline $\mathrm{Mn}$ & 2,0 & $3,46 \pm 0,12$ & $6,78 \pm 0,35$ & $4,22 \pm 0,10$ & $4,96 \pm 0,37$ & $8,50 \pm 0,44$ & $5,54 \pm 0,40$ \\
\hline $\mathrm{Fe}$ & 30 & $37,62 \pm 0,35$ & $27,38 \pm 0,74$ & $15,76 \pm 0,71$ & $39,98 \pm 1,10$ & $32,28 \pm 0,83$ & $24,16 \pm 0,90$ \\
\hline $\mathrm{Cu}$ & 10 & $12,88 \pm 0,68$ & $17,04 \pm 0,62$ & $12,98 \pm 0,41$ & $8,38 \pm 1,24$ & $13,78 \pm 0,94$ & $12,34 \pm 0,32$ \\
\hline $\mathrm{Pb}$ & 1,0 & $7,40 \pm 0,38$ & $18,30 \pm 1,14$ & $16,54 \pm 1,56$ & $6,40 \pm 0,93$ & $12,76 \pm 1,26$ & $11,22 \pm 0,48$ \\
\hline $\mathrm{Co}$ & 0,08 & $1,52 \pm 0,14$ & $2,20 \pm 0,02$ & $1,66 \pm 0,12$ & $0,45 \pm 0,04$ & $1,55 \pm 0,06$ & $1,04 \pm 0,08$ \\
\hline $\mathrm{Ni}$ & 0,5 & $3,17 \pm 0,09$ & $3,77 \pm 0,07$ & $1,66 \pm 0,12$ & $2,32 \pm 0,10$ & $2,64 \pm 0,08$ & $2,98 \pm 0,21$ \\
\hline $\mathrm{Cd}$ & 0,2 & $3,92 \pm 0,19$ & $4,50 \pm 0,21$ & $3,78 \pm 0,23$ & $2,48 \pm 0,17$ & $3,8 \pm 0,66$ & $2,84 \pm 0,25$ \\
\hline \multicolumn{8}{|c|}{ Pond of "Bila Tserkva Experimental Hydrobiological Station" } \\
\hline & & \multicolumn{3}{|c|}{$\mathrm{n}=5$} & \multicolumn{3}{|c|}{$\mathrm{n}=5$} \\
\hline $\mathrm{Zn}$ & 40,0 & $32,10 \pm 1,35$ & $37,36 \pm 1,10$ & $19,48 \pm 0,66$ & $40,82 \pm 1,37$ & $45,26 \pm 2,43$ & $22,30 \pm 0,53$ \\
\hline $\mathrm{Mn}$ & 2,0 & $4,92 \pm 0,56$ & $8,58 \pm 0,49$ & $5,64 \pm 0,50$ & $4,88 \pm 0,45$ & $8,66 \pm 0,44$ & $5,70 \pm 0,43$ \\
\hline $\mathrm{Fe}$ & 30 & $41,08 \pm 1,09$ & $28,8 \pm 1,04$ & $19,46 \pm 0,81$ & $40,80 \pm 1,05$ & $29,04 \pm 1,27$ & $20,10 \pm 0,77$ \\
\hline \multirow[t]{2}{*}{1} & 2 & 3 & 4 & 5 & 6 & 7 & 8 \\
\hline & & \multicolumn{3}{|c|}{ Autumn 2017} & \multicolumn{3}{|c|}{ Autumn 2018} \\
\hline & & \multicolumn{3}{|c|}{$\mathrm{n}=5$} & \multicolumn{3}{|c|}{$\mathrm{n}=5$} \\
\hline $\mathrm{Cu}$ & 10 & $8,54 \pm 1,11$ & $13,28 \pm 0,70$ & $10,50 \pm 0,74$ & $8,94 \pm 1,19$ & $14,48 \pm 0,77$ & $11,32 \pm 0,74$ \\
\hline $\mathrm{Pb}$ & 1,0 & $6,30 \pm 0,59$ & $10,1 \pm 0,83$ & $8,92 \pm 0,60$ & $6,00 \pm 0,78$ & $10,6 \pm 0,70$ & $9,80 \pm 0,65$ \\
\hline $\mathrm{Co}$ & 0,08 & $0,52 \pm 0,07$ & $1,19 \pm 0,08$ & $1,03 \pm 0,09$ & $0,51 \pm 0,05$ & $1,28 \pm 0,09$ & $1,06 \pm 0,09$ \\
\hline $\mathrm{Ni}$ & 0,5 & $3,33 \pm 0,15$ & $2,96 \pm 0,07$ & $3,42 \pm 0,15$ & $2,32 \pm 0,10$ & $2,64 \pm 0,08$ & $2,98 \pm 0,21$ \\
\hline $\mathrm{Cd}$ & 0,2 & $1,90 \pm 0,29$ & $2,82 \pm 0,19$ & $2,06 \pm 0,32$ & $2,48 \pm 0,17$ & $3,80 \pm 0,66$ & $2,84 \pm 0,25$ \\
\hline \multicolumn{8}{|c|}{ Pond of "Training, Research and Production Laboratory of Fish Farming" } \\
\hline & & \multicolumn{3}{|c|}{$\mathrm{n}=5$} & \multicolumn{3}{|c|}{$\mathrm{n}=5$} \\
\hline $\mathrm{Zn}$ & 40,0 & $43,86 \pm 1,57$ & $44,56 \pm 0,83$ & $26,42 \pm 0,61$ & $19,98 \pm 0,53$ & $27,64 \pm 1,38$ & $13,50 \pm 1,08$ \\
\hline $\mathrm{Mn}$ & 2,0 & $5,04 \pm 0,36$ & $8,88 \pm 0,46$ & $5,64 \pm 0,60$ & $2,48 \pm 0,37$ & $6,02 \pm 0,57$ & $3,70 \pm 0,10$ \\
\hline $\mathrm{Fe}$ & 30 & $37,34 \pm 0,74$ & $34,82 \pm 1,44$ & $23,56 \pm 0,89$ & $31,70 \pm 0,82$ & $26,46 \pm 0,91$ & $16,28 \pm 0,62$ \\
\hline $\mathrm{Cu}$ & 10 & $9,10 \pm 0,41$ & $14,38 \pm 0,32$ & $10,64 \pm 0,59$ & $7,26 \pm 1,22$ & $11,84 \pm 0,49$ & $9,58 \pm 0,51$ \\
\hline $\mathrm{Pb}$ & 1,0 & $4,72 \pm 0,24$ & $11,16 \pm 0,76$ & $8,22 \pm 0,58$ & $4,58 \pm 0,38$ & $8,82 \pm 0,62$ & $4,50 \pm 0,28$ \\
\hline $\mathrm{Co}$ & 0,08 & $0,38 \pm 0,03$ & $1,29 \pm 0,07$ & $0,72 \pm 0,04$ & $0,83 \pm 0,54$ & $0,46 \pm 0,04$ & $0,65 \pm 0,01$ \\
\hline $\mathrm{Ni}$ & 0,5 & $1,73 \pm 0,07$ & $2,35 \pm 0,09$ & $2,07 \pm 0,18$ & $1,99 \pm 0,10$ & $1,91 \pm 0,09$ & $1,45 \pm 0,04$ \\
\hline $\mathrm{Cd}$ & 0,2 & $2,37 \pm 0,18$ & $3,32 \pm 0,23$ & $1,88 \pm 0,18$ & $3,72 \pm 0,10$ & $3,78 \pm 0,35$ & $3,32 \pm 0,29$ \\
\hline
\end{tabular}

Table 3. Heavy metals content and distribution in the organs and tissues of (H2) age group of hybrid silver $x$ bighead carp form, harvested in the wintering pond in the spring of $2017 \& 2018$,

$\mathrm{M} \pm \mathrm{m}, \mathrm{n}=5, \mu \mathrm{g} / \mathrm{kg}$ of raw weight

\begin{tabular}{|c|c|c|c|c|c|c|c|}
\hline $\begin{array}{c}\text { Heavy } \\
\text { metals }\end{array}$ & $\begin{array}{c}\text { Max } \\
\text { admissible }\end{array}$ & Liver & Gills & Muscles & Liver & Gills & Muscles \\
\hline 1 & 2 & 3 & 4 & 5 & 6 & 7 & 8 \\
\hline \multicolumn{7}{|c|}{ Autumn 2017 } \\
\hline \multicolumn{7}{|c|}{ Pond of “Nyvka” } \\
\hline \multicolumn{7}{|c|}{$\mathrm{n}=5$} \\
\hline $\mathrm{Zn}$ & 40,0 & $27,16 \pm 0,70$ & $30,18 \pm 1,05$ & $15,18 \pm 0,81$ & $29,90 \pm 0,72$ & $34,38 \pm 1,09$ & $13,26 \pm 0,22$ \\
\hline $\mathrm{Mn}$ & 2,0 & $2,78 \pm 0,22$ & $5,72 \pm 0,43$ & $3,56 \pm 0,18$ & $3,04 \pm 0,12$ & $5,12 \pm 0,26$ & $3,84 \pm 0,22$ \\
\hline $\mathrm{Fe}$ & 30 & $36,04 \pm 0,55$ & $26,02 \pm 0,45$ & $14,86 \pm 0,47$ & $39,46 \pm 6,45$ & $25,12 \pm 0,80$ & $14,58 \pm 0,57$ \\
\hline $\mathrm{Cu}$ & 10 & $10,14 \pm 0,78$ & $13,04 \pm 0,76$ & $12,20 \pm 0,42$ & $8,08 \pm 0,32$ & $11,12 \pm 0,43$ & $8,24 \pm 0,43$ \\
\hline $\mathrm{Pb}$ & 1,0 & $7,14 \pm 0,53$ & $16,0 \pm 0,79$ & $11,72 \pm 0,83$ & $7,96 \pm 0,32$ & $13,18 \pm 1,05$ & $13,38 \pm 0,90$ \\
\hline $\mathrm{Co}$ & 0,08 & $1,09 \pm 0,12$ & $1,48 \pm 0,14$ & $1,42 \pm 0,11$ & $1,15 \pm 0,10$ & $1,49 \pm 0,17$ & $1,15 \pm 0,05$ \\
\hline $\mathrm{Ni}$ & 0,5 & $2,84 \pm 0,08$ & $3,26 \pm 0,10$ & $2,71 \pm 0,10$ & $2,56 \pm 0,17$ & $3,10 \pm 0,11$ & $3,31 \pm 0,17$ \\
\hline $\mathrm{Cd}$ & 0,2 & $1,68 \pm 0,32$ & $3,80 \pm 0,34$ & $3,39 \pm 0,12$ & $3,30 \pm 0,09$ & $3,96 \pm 0,19$ & $3,20 \pm 0,05$ \\
\hline \multicolumn{7}{|c|}{ Pond of “Bila Tserkva Experimental Hydrobiological Station” } \\
\hline
\end{tabular}




\begin{tabular}{|c|c|c|c|c|c|c|c|}
\hline $\begin{array}{l}\text { Heavy } \\
\text { metals }\end{array}$ & $\begin{array}{c}\text { Max } \\
\text { admissible }\end{array}$ & Liver & Gills & Muscles & Liver & Gills & Muscles \\
\hline & & \multicolumn{3}{|c|}{$\mathrm{n}=5$} & \multicolumn{3}{|c|}{$\mathrm{n}=5$} \\
\hline $\mathrm{Zn}$ & 40,0 & $23,48 \pm 0,43$ & $31,82 \pm 1,46$ & $15,00 \pm 0,49$ & $25,68 \pm 0,43$ & $33,48 \pm 1,36$ & $16,92 \pm 0,68$ \\
\hline $\mathrm{Mn}$ & 2,0 & $4,06 \pm 0,13$ & $5,20 \pm 0,32$ & $5,92 \pm 0,10$ & $5,56 \pm 0,58$ & $7,44 \pm 0,48$ & $6,72 \pm 0,14$ \\
\hline $\mathrm{Fe}$ & 30 & $40,02 \pm 1,59$ & $21,04 \pm 0,29$ & $12,52 \pm 0,58$ & $41,29 \pm 0,95$ & $23,88 \pm 0,60$ & $14,68 \pm 0,62$ \\
\hline $\mathrm{Cu}$ & 10 & $12,38 \pm 0,57$ & $10,08 \pm 0,27$ & $11,92 \pm 0,48$ & $14,40 \pm 0,35$ & $12,12 \pm 0,38$ & $14,80 \pm 0,46$ \\
\hline $\mathrm{Pb}$ & 1,0 & $10,22 \pm 0,37$ & $13,88 \pm 0,37$ & $9,92 \pm 0,12$ & $12,04 \pm 0,32$ & $15,96 \pm 0,22$ & $11,90 \pm 0,41$ \\
\hline Co & 0,08 & $1,28 \pm 0,05$ & $1,20 \pm 0,04$ & $1,18 \pm 0,04$ & $1,51 \pm 0,06$ & $1,26 \pm 0,05$ & $1,26 \pm 0,09$ \\
\hline $\mathrm{Ni}$ & 0,5 & $3,71 \pm 0,13$ & $4,02 \pm 0,07$ & $4,08 \pm 0,07$ & $3,36 \pm 0,11$ & $3,83 \pm 0,06$ & $3,76 \pm 0,04$ \\
\hline $\mathrm{Cd}$ & 0,2 & $2,88 \pm 0,06$ & $2,86 \pm 0,06$ & $2,90 \pm 0,00$ & $3,16 \pm 0,04$ & $2,78 \pm 0,42$ & $3,22 \pm 0,02$ \\
\hline \multicolumn{8}{|c|}{ Pond of "Training, Research and Production Laboratory of Fish Farming" } \\
\hline & & \multicolumn{3}{|c|}{$\mathrm{n}=5$} & \multicolumn{3}{|c|}{$\mathrm{n}=5$} \\
\hline $\mathrm{Zn}$ & 40,0 & $21,18 \pm 1,81$ & $30,46 \pm 1,25$ & $14,12 \pm 1,13$ & $17,78 \pm 1,66$ & $13,70 \pm 1,37$ & $9,72 \pm 0,37$ \\
\hline $\mathrm{Mn}$ & 2,0 & $3,72 \pm 0,71$ & $6,82 \pm 0,77$ & $4,58 \pm 0,45$ & $8,62 \pm 1,79$ & $7,66 \pm 0,90$ & $2,98 \pm 0,36$ \\
\hline $\mathrm{Fe}$ & 30 & $43,98 \pm 2,89$ & $19,14 \pm 0,79$ & $15,88 \pm 1,30$ & $24,86 \pm 2,89$ & $21,16 \pm 1,46$ & $10,96 \pm 0,91$ \\
\hline $\mathrm{Cu}$ & 10 & $8,46 \pm 1,32$ & $7,78 \pm 1,11$ & $7,24 \pm 1,32$ & $10,18 \pm 0,96$ & $6,78 \pm 0,70$ & $5,66 \pm 0,23$ \\
\hline $\mathrm{Pb}$ & 1,0 & $12,80 \pm 1,39$ & $9,54 \pm 1,52$ & $8,96 \pm 0,84$ & $9,54 \pm 0,90$ & $11,30 \pm 1,24$ & $15,04 \pm 1,45$ \\
\hline Co & 0,08 & $0,76 \pm 0,06$ & $0,73 \pm 0,06$ & $0,58 \pm 0,07$ & $0,49 \pm 0,008$ & $0,50 \pm 0,06$ & $0,72 \pm 0,06$ \\
\hline $\mathrm{Ni}$ & 0,5 & $3,74 \pm 0,26$ & $3,57 \pm 0,38$ & $3,80 \pm 0,24$ & $2,64 \pm 0,28$ & $3,09 \pm 0,21$ & $3,35 \pm 0,19$ \\
\hline $\mathrm{Cd}$ & 0,2 & $3,12 \pm 0,16$ & $3,34 \pm 0,24$ & $3,26 \pm 0,21$ & $2,90 \pm 0,13$ & $2,46 \pm 0,16$ & $2,70 \pm 0,06$ \\
\hline
\end{tabular}

The general contents dynamics of heavy metals in the organs and tissues of the hybrid of silver $\mathrm{x}$ bighead carp in some reservoirs (including ponds) is practically identical for all studied reservoirs for 2017-2019. There are small differences in performance due to the specific conditions of the existence of carp in each reservoir, however, the general features of the accumulation of heavy metals remain.

The general dynamics of the content of heavy metals of the hybrid of silver $\mathrm{x}$ bighead carp in the liver, gills and muscles is also quite similar for all age groups of fish in different seasons (spring, summer, autumn) and years of research (2017-2019). There are some differences in the indicators due to the specific conditions of the existence of carp for each season and year of research, but the general patterns of heavy metal content in fish remain (Fig. 1).

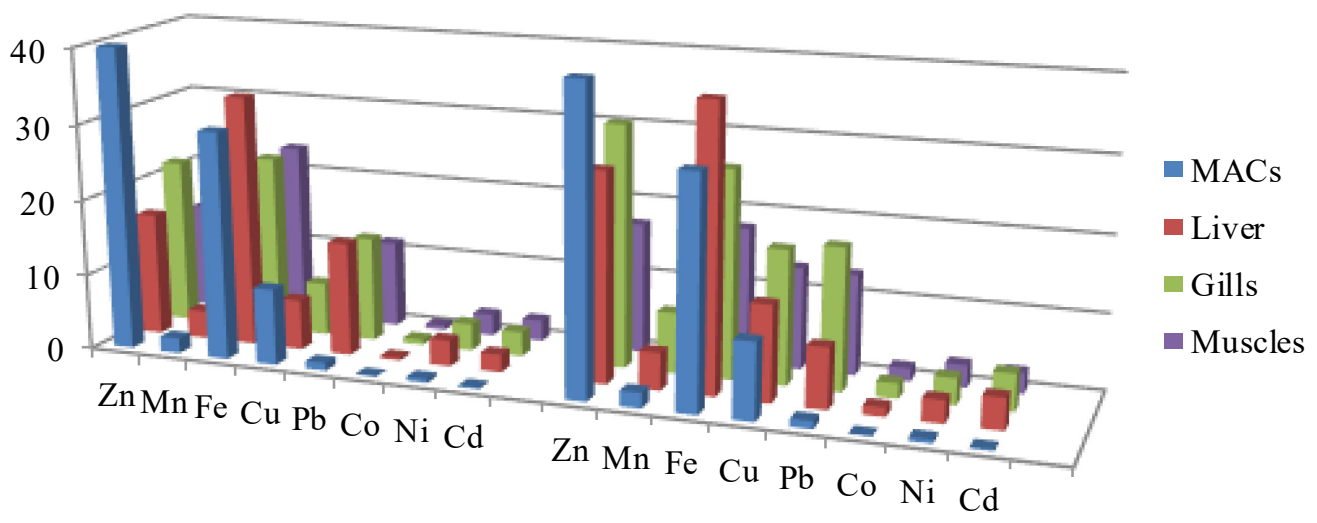

Fig. 1. The general dynamics of the content of heavy metals ( $\mathrm{mg} / \mathrm{kg}$ of raw mass) in the liver, gills and muscles of a hybrid of white with variegated silver carp in ponds in 2017 (left) and 2018 (right).

Given the dynamics of the content of heavy metals in the liver, gills and muscles of the hybrid silver $\mathrm{x}$ bighead carp in reservoirs for 2017-2019, further analysis of their accumulation will be carried out for individual metals. 
Zinc. The highest concentration of $\mathrm{Zn}$ in the organs and tissues of (H1) hybrid silver $x$ bighead carp form that were harvested in the spring of 2017-2018, was observed in fish from the area with the lowest urbanization level - "Training, Research and Production Laboratory of Fish Farming". However, in all abovementioned 3 enterprises the content of this heavy metal varied widely - from 11,24 to $34,20 \mu \mathrm{g} / \mathrm{kg}$ raw weight. In particular, its content varied from 11,24 to $29,32 \mu \mathrm{g} / \mathrm{kg}$ raw weight in fish from the enterprise "Nyvka" with highest level of anthropogenic pressure. This index for fish from the enterprise "Bila Tserkva Experimental Hydrobiological Station" varied from 15,14 to $34,20 \mu \mathrm{g} / \mathrm{kg}$ raw weight and from 11,38 to $32,30 \mu \mathrm{g} / \mathrm{kg}$ raw weight in fish from enterprise "Training, Research and Production Laboratory of Fish Farming". Note that according to our investigations, the content of $\mathrm{Zn}$ in the organism of the above-mentioned age group of fish did not exceed of the maximum allowable concentrations (MAC $40 \mathrm{mg} / \mathrm{kg}$ raw weight) and did not reveal its dependence on the urbanization degree, and hence the anthropogenic load on it. Due to the $\mathrm{Zn}$ content increase in the organs and tissues of the (H1) hybrid, the following row is logically formed: gills $>$ liver $>$ muscles.

The highest concentration of $\mathrm{Zn}$ in the organs and tissues of $(\mathrm{H} 1+)$ hybrid silver $x$ bighead carp form that were harvested in the autumn of 2017-2018, was observed in fish from the area with the highest level of urbanization - "Nyvka". However, in all of abovementioned 3 enterprises the content of this heavy metal varied in a wide range - from 13,50 to $46,36 \mu \mathrm{g} / \mathrm{kg}$ raw weight. In particular, in fish from the enterprise "Nyvka" with highest level of anthropogenic pressure its content varied from 15,02 to 46,36 $\mu \mathrm{g} / \mathrm{kg}$ raw weight. This index for fish from the enterprise "Bila Tserkva Experimental Hydrobiological Station" varied from 19,48 to 45,26 $\mu \mathrm{g} / \mathrm{kg}$ raw weight and from 13,50 to 44,56 $\mu \mathrm{g} / \mathrm{kg}$ raw weight in fish from enterprise "Training, Research and Production Laboratory of Fish Farming". Note that according to our investigations, the $\mathrm{Zn}$ content in the organism of the above-mentioned age group exceed the MAC in fish from all enterprises, which is a clear example of the ability of these heavy metals to have a cumulative effect, which manifests itself with the age. In addition, this effect explains the dependence of $\mathrm{Zn}$ concentration on the urbanization level of the territory, and, as a consequence, on the strength of the anthropogenic load. Due to the $\mathrm{Zn}$ content increase in the organs and tissues of the $(\mathrm{H} 1+)$, the following row is logically formed: gills $>$ liver $>$ muscles.

The highest concentration of $\mathrm{Zn}$ in the organs and tissues of (H2) hybrid silver $x$ bighead carp form that were harvested in the spring of 2017-2018, was observed in fish from the area with the highest level of urbanization - "Nyvka". However, in all abovementioned 3 enterprises the content of this heavy metal varied in a wide range - from 9,72 to $34,38 \mu \mathrm{g} / \mathrm{kg}$ raw weight. In particular, in the fish from the enterprise "Nyvka" with the highest level of anthropogenic pressure its content varied from 13,26 to 34,38 $\mu \mathrm{g} / \mathrm{kg}$ raw weight. This index for fish from the enterprise "Bila Tserkva Experimental Hydrobiological Station" varied from 15,0 to 33,48 $\mu \mathrm{g} / \mathrm{kg}$ raw weight and from 9,72 to $30,46 \mu \mathrm{g} / \mathrm{kg}$ raw weight in fish from enterprise "Training, Research and Production Laboratory of Fish Farming". Accordingly, the content of $\mathrm{Zn}$ in the organisms of the sampling fish of the age group of (H2) does not exceed the MAC, which can be explained by compliance with all technological requirements for the wintering process. The degree of $\mathrm{Zn}$ concentration increases in the organs and tissues of all harvested fish age groups from 3 above mentioned different enterprises in a different way. In turn, this determines the relevance of further research determinants of seasonal changes in the compounds of this heavy metal in ecotopes.

Manganese. The highest concentration of $\mathrm{Mn}$ in the organs and tissues of (H1) hybrid silver $x$ bighead carp form that were harvested in the spring of 2017-2018, was observed in fish from the area with the lowest level of urbanization - "Training, Research and Production Laboratory of Fish Farming". However, in all of abovementioned 3 enterprises the content of this heavy metal varied widely - from 2,96 to $7,98 \mu \mathrm{g} / \mathrm{kg}$ raw weight. In particular, its content varied from 2,96 to $6,08 \mu \mathrm{g}$ / kg raw weight in fish from the enterprise "Nyvka" with highest level of anthropogenic pressure. This index for fish from the enterprise "Bila Tserkva Experimental Hydrobiological Station" varied from 4,04 to $6,32 \mu \mathrm{g} / \mathrm{kg}$ raw weight and from 3,56 to 7,98 $\mu \mathrm{g} / \mathrm{kg}$ raw weight in fish from enterprise "Training, Research and Production Laboratory of Fish Farming". Note that according to 
our investigations, the content of $\mathrm{Mn}$ in the organism of the above-mentioned age group of fish exceed the maximum allowable concentrations (MAC 2,0 $\mathrm{mg} / \mathrm{kg}$ raw weight) in fish from all enterprises. For example, in the organism of fish from the enterprise "Nyvka" its content exceeded the MAC by 1,5-3,0 times, from the enterprise "Bila Tserkva Experimental Hydrobiological Station" - by 2,0-3,2 times and from the enterprise "Training, Research and Production Laboratory of Fish Farming" - by 1,8-4,0 times. Due to the Mn content increase in the organs and tissues of the $(\mathrm{H} 1)$, the following row is logically formed: gills $>$ liver $>$ muscles.

The highest concentration of $\mathrm{Mn}$ in the organs and tissues of $(\mathrm{H} 1+)$ hybrid silver $x$ bighead carp form that were harvested in the autumn of 2017-2018, was observed in fish from the area with the middle level of urbanization - "Bila Tserkva Experimental Hydrobiological Station". However, in all of abovementioned 3 enterprises the content of this heavy metal varied widely - from 2,48 to $8,88 \mu \mathrm{g} / \mathrm{kg}$ raw weight. In particular, in fish from the enterprise "Bila Tserkva Experimental Hydrobiological Station" with middle level of anthropogenic pressure its content varied from 4,92 to $8,66 \mu \mathrm{g} / \mathrm{kg}$ raw weight. This index for fish from the enterprise "Nyvka" varied from 3,46 to $8,50 \mu \mathrm{g} / \mathrm{kg}$ raw weight and from 2,48 to $8,88 \mu \mathrm{g} / \mathrm{kg}$ raw weight in fish from enterprise "Training, Research and Production Laboratory of Fish Farming". Note that according to our investigations, the content of $\mathrm{Mn}$ in the organism of the above mentioned age group of fish exceed the MAC in fish from all enterprises: by 3,46-8,50 times ("Nyvka"), by 2,5-4,43 times ("Bila Tserkva Experimental Hydrobiological Station") and by 1,2-4,44 times ("Training, Research and Production Laboratory of Fish Farming"). Due to the Mn content increase in the organs and tissues of the $(\mathrm{H} 1+)$, the following row is logically formed: gills $>$ liver $>$ muscles.

The highest concentration of $\mathrm{Mn}$ in the organs and tissues of (H2) hybrid silver $x$ bighead carp form that were harvested in the spring of 2017-2018, was observed in fish from the area with the lowest level of urbanization - "Training, Research and Production Laboratory of Fish Farming". However, in all of abovementioned 3 enterprises the content of this heavy metal varied widely from 2,78 to 8,62 $\mu \mathrm{g} / \mathrm{kg}$ raw weight. In particular, in fish from the enterprise "Training, Research and Production Laboratory of Fish Farming" with the lowest level of anthropogenic pressure its content varied from 5,98 to $8,62 \mu \mathrm{g} / \mathrm{kg}$ raw weight. This index for fish from the enterprise "Nyvka" varied from 2,78 to $5,72 \mu \mathrm{g} / \mathrm{kg}$ raw weight and from 4,06 to 7,44 $\mu \mathrm{g} / \mathrm{kg}$ raw weight in fish from enterprise "Bila Tserkva Experimental Hydrobiological Station". Accordingly, the content of $\mathrm{Mn}$ in the organisms of the sampling fish of the age group of $(\mathrm{H} 2)$ exceed the MAC: by 1,4-2,8 times in fish from enterprise "Nyvka", by 1,4-2,9 times in fish from enterprise "Bila Tserkva Experimental Hydrobiological Station" and by 1,5-4,3 times in fish from enterprise "Training, Research and Production Laboratory of Fish Farming". The degree of Mn concentration increases in the organs and tissues of (H2) hybrid, harvested from 3 above mentioned different enterprises wasn't identical. In turn, this determines the relevance of further research determinants of seasonal changes in the compounds of this heavy metal in ecotopes.

Ferum. The highest concentration of $\mathrm{Fe}$ in the organs and tissues of (H1) hybrid silver $x$ bighead carp form that were harvested in the spring of 2017-2018, was observed in fish from the area with the lowest level of urbanization - "Training, Research and Production Laboratory of Fish Farming". However, in all of abovementioned 3 enterprises the content of this heavy metal varied widely - from 13,90 to $45,30 \mu \mathrm{g} / \mathrm{kg}$ raw weight. In particular, its content varied from 18,92 to $37,32 \mu \mathrm{g} / \mathrm{kg}$ raw weight in fish from the enterprise "Nyvka" with highest level of anthropogenic pressure. This index for fish from the enterprise "Bila Tserkva Experimental Hydrobiological Station" varied from 13,90 to $45,30 \mu \mathrm{g} / \mathrm{kg}$ raw weight and from 17,88 to $42,24 \mu \mathrm{g} / \mathrm{kg}$ raw weight in fish from enterprise "Training, Research and Production Laboratory of Fish Farming". Note that according to our investigations, the content of $\mathrm{Fe}$ in the organism of the above-mentioned age group of fish exceed of the maximum allowable concentrations (MAC $10 \mathrm{mg} / \mathrm{kg}$ raw weight) in fish from all enterprises. For example, in the organism of fish from the enterprise "Nyvka" its content exceeded the MAC: by 1,1-1,2 times, from the enterprise "Bila Tserkva Experimental Hydrobiological Station" - by 1,5 time and from the enterprise "Training, Research and Production Laboratory of Fish Farming" - by 1,2-1,4 times. Due to the Fe content increase in the organs and tissues of the (H1), the following row is logically formed: liver $>$ gills $>$ muscles. 
The highest concentration of $\mathrm{Fe}$ in the organs and tissues of $(\mathrm{H} 1+)$ hybrid silver $x$ bighead carp form that were harvested in the autumn of 2017-2018, was observed in fish from the area with the highest level of urbanization - "Nyvka". However, in all of abovementioned 3 enterprises the content of this heavy metal varied widely - from 2,48 to $39,98 \mu \mathrm{g} / \mathrm{kg}$ raw weight. In particular, in fish from the enterprise "Bila Tserkva Experimental Hydrobiological Station" with middle level of anthropogenic pressure its content varied from 4,92 to $8,66 \mu \mathrm{g} / \mathrm{kg}$ raw weight. This index for fish from the enterprise "Nyvka" varied from 15,76 to $39,98 \mu \mathrm{g} / \mathrm{kg}$ raw weight and from 2,48 to $8,88 \mu \mathrm{g} / \mathrm{kg}$ raw weight in fish from enterprise "Training, Research and Production Laboratory of Fish Farming". Note that according to our investigations, the content of Fe in the organism of the above mentioned age group of fish exceed the MAC in fish from all enterprises: by 2,5-4,43 times ("Nyvka"), by 1,1-1,2 times and by 1,1-1,3 times ("Training, Research and Production Laboratory of Fish Farming" and "Bila Tserkva Experimental Hydrobiological Station"). Due to the Fe content increase in the organs and tissues of the $(\mathrm{H} 1+)$, the following row is logically formed: liver $>$ gills $>$ muscles.

The highest concentration of $\mathrm{Fe}$ in the organs and tissues of (H2) hybrid silver $x$ bighead carp form that were harvested in the spring of 2017-2018, was observed in fish from the area with the lowest level of urbanization - "Training, Research and Production Laboratory of Fish Farming". However, in all of abovementioned 3 enterprises the content of this heavy metal varied widely from 10,96 to $43,98 \mu \mathrm{g} / \mathrm{kg}$ raw weight. In particular, in fish from the enterprise "Training, Research and Production Laboratory of Fish Farming" with the lowest level of anthropogenic pressure its content varied from 10,96 to $43,98 \mu \mathrm{g} / \mathrm{kg}$ raw weight. This index for fish from the enterprise "Nyvka" varied from 14,58 to $39,46 \mu \mathrm{g} / \mathrm{kg}$ raw weight and from 12,52 to 41,29 $\mu \mathrm{g} / \mathrm{kg}$ raw weight in fish from enterprise "Bila Tserkva Experimental Hydrobiological Station". Accordingly, the content of $\mathrm{Fe}$ in the organisms of the sampling fish of the age group of (H2) exceed the MAC: by 1,2-1,3 times in fish from enterprise "Nyvka", by 1,3-1,4 times in fish from enterprise "Bila Tserkva Experimental Hydrobiological Station" and by 1,5 times in fish from enterprise "Training, Research and Production Laboratory of Fish Farming". Due to the Fe content increase in the organs and tissues of the (H2), the following row is logically formed: liver $>$ gills $>$ muscles.

Cuprum. The highest concentration of $\mathrm{Cu}$ in the organs and tissues of (H1) hybrid silver $x$ bighead carp form that were harvested in the spring of 2017-2018, was observed in fish from the area with the lowest level of urbanization - "Training, Research and Production Laboratory of Fish Farming". However, in all of above-mentioned 3 enterprises the content of this heavy metal varied widely - from 5,46 to $18,54 \mu \mathrm{g} / \mathrm{kg}$ raw weight. In particular, in fish from the enterprise "Nyvka" with highest level of anthropogenic pressure its content varied from 5,46 to $13,56 \mu \mathrm{g} / \mathrm{kg}$ raw weight. This index for fish from the enterprise "Bila Tserkva Experimental Hydrobiological Station" varied from 7,12 to $10,86 \mu \mathrm{g} / \mathrm{kg}$ raw weight and from 12,54 to $18,54 \mu \mathrm{g} / \mathrm{kg}$ raw weight in fish from enterprise "Training, Research and Production Laboratory of Fish Farming". Note that according to our investigations, the content of $\mathrm{Cu}$ in the organism of the above-mentioned age group of fish exceed of the maximum allowable concentrations (MAC $10 \mathrm{mg} / \mathrm{kg}$ raw weight) in fish from all enterprises. The degree of $\mathrm{Cu}$ concentration increases in the organs and tissues of (H1) hybrid, harvested from 3 above mentioned different enterprises wasn't identical. In turn, this determines the relevance of further research determinants of seasonal changes in the compounds of this heavy metal in ecotopes.

The highest concentration of $\mathrm{Cu}$ in the organs and tissues of $(\mathrm{H} 1+)$ hybrid silver $x$ bighead carp form that were harvested in the autumn of 2017-2018, was observed in fish from the area with the highest level of urbanization - "Nyvka". However, in all of abovementioned 3 enterprises the content of this heavy metal varied widely - from 7,26 to $17,04 \mu \mathrm{g} / \mathrm{kg}$ raw weight. In particular, its content varied from 8,38 to $17,04 \mu \mathrm{g} / \mathrm{kg}$ raw weight in fish from the enterprise "Nyvka" with highest level of anthropogenic pressure. This index for fish from the enterprise "Bila Tserkva Experimental Hydrobiological Station" varied from 8,54 to $14,48 \mu \mathrm{g} / \mathrm{kg}$ raw weight and from 7,26 to $14,38 \mu \mathrm{g} / \mathrm{kg}$ raw weight in fish from enterprise "Training, Research and Production Laboratory 
of Fish Farming". Note that according to our investigations, the $\mathrm{Cu}$ content in the organism of the above-mentioned age group of fish exceed the MAC in fish from all enterprises: by 1,2-1,7 times ("Nyvka"), by 1,1-1,4 times ("Bila Tserkva Experimental Hydrobiological Station" and "Training, Research and Production Laboratory of Fish Farming"). Due to the $\mathrm{Cu}$ content increase in the organs and tissues of the $(\mathrm{H} 1+)$, the following row is logically formed: gills $>$ muscles $>$ liver.

The highest $\mathrm{Cu}$ concentration in the organs and tissues of (H2) hybrid silver $x$ bighead carp form that were harvested in the spring of 2017-2018, was observed in fish from the area with the middle level of urbanization - "Bila Tserkva Experimental Hydrobiological Station". However, in all of abovementioned 3 enterprises the content of this heavy metal varied widely - from 5,66 to $14,8 \mu \mathrm{g} / \mathrm{kg}$ raw weight. In particular, its content varied from 10,08 to $14,80 \mu \mathrm{g} / \mathrm{kg}$ raw weight in fish from the enterprise "Bila Tserkva Experimental Hydrobiological Station" with the middle level of anthropogenic pressure. This index for fish from the enterprise "Nyvka" varied from 8,08 to $13,04 \mu \mathrm{g} / \mathrm{kg}$ raw weight and from 5,66 to $10,18 \mu \mathrm{g} / \mathrm{kg}$ raw weight in fish from enterprise "Training, Research and Production Laboratory of Fish Farming". Accordingly, the content of Cu in the organisms of the sampling fish of the age group of (H2) exceed the MAC in all enterprises. The degree of $\mathrm{Cu}$ concentration increases in the organs and tissues of (H2) hybrid, harvested from 3 above mentioned different enterprises wasn't identical. In turn, this determines the relevance of further research determinants of seasonal changes in the compounds of this heavy metal in ecotopes.

Plumbum. The highest concentration of $\mathrm{Pb}$ in the organs and tissues of $(\mathrm{H} 1)$ hybrid silver $x$ bighead carp form that were harvested in the spring of 2017-2018, was observed in fish from the area with the lowest level of urbanization - "Training, Research and Production Laboratory of Fish Farming". However, in all of abovementioned 3 enterprises the content of this heavy metal varied widely - from 7,28 to $21,20 \mu \mathrm{g} / \mathrm{kg}$ raw weight. In particular, its content varied from 7,28 to 17,0 $\mu \mathrm{g} / \mathrm{kg}$ raw weight in fish from the enterprise "Nyvka" with highest level of anthropogenic pressure. This index for fish from the enterprise "Bila Tserkva Experimental Hydrobiological Station" varied from 9,64 to 13,90 $\mu \mathrm{g} / \mathrm{kg}$ raw weight and from 7,94 to $21,20 \mu \mathrm{g} / \mathrm{kg}$ raw weight in fish from enterprise "Training, Research and Production Laboratory of Fish Farming". Note that according to our investigations, the content of $\mathrm{Pb}$ in the organism of the above mentioned age group of fish exceed the maximum allowable concentrations (MAC 1,0 mg / kg raw weight) in fish from all enterprises: by 7,3-17,0 times ("Nyvka"), by 9,6-13,9 times ("Bila Tserkva Experimental Hydrobiological Station") and by 7,9-21,2 times ("Training, Research and Production Laboratory of Fish Farming"). The degree of $\mathrm{Pb}$ concentration increase in the organs and tissues of (H1) hybrid, harvested from 3 above mentioned different enterprises wasn't identical. In turn, this determines the relevance of further research determinants of seasonal changes in the compounds of this heavy metal in ecotopes.

The highest concentration of $\mathrm{Pb}$ in the organs and tissues of $(\mathrm{H} 1+)$ hybrid silver $x$ bighead carp form that were harvested in the autumn of 2017-2018, was observed in fish from the area with the highest level of urbanization - "Nyvka". However, in all of abovementioned 3 enterprises the content of this heavy metal varied widely - from 4,58 to $18,30 \mu \mathrm{g} / \mathrm{kg}$ raw weight. In particular, its content varied from 6,40 to $18,30 \mu \mathrm{g} / \mathrm{kg}$ raw weight in fish from the enterprise "Nyvka" with highest level of anthropogenic pressure. This index for fish from the enterprise "Bila Tserkva Experimental Hydrobiological Station" varied from 6,0 to $10,6 \mu \mathrm{g} / \mathrm{kg}$ raw weight and from 4,58 to $11,16 \mu \mathrm{g} / \mathrm{kg}$ raw weight in fish from enterprise "Training, Research and Production Laboratory of Fish Farming". Note that according to our investigations, the $\mathrm{Pb}$ content in the organism of the above mentioned age group of fish exceed the MAC in fish from all enterprises: by 6,4-18,3 times ("Nyvka"), by 6,0-10,6 times ("Bila Tserkva Experimental Hydrobiological Station") and by 4,611,2 times ("Training, Research and Production Laboratory of Fish Farming"). Due to the Pb content increase in the organs and tissues of the $(\mathrm{H} 1+)$, the following row is logically formed: gills $>$ muscles $>$ liver.

The highest concentration of $\mathrm{Pb}$ in the organs and tissues of (H2) hybrid silver $x$ bighead carp form that were harvested in the spring of 2017-2018, was observed in fish from the area with 
the middle level of urbanization - "Bila Tserkva Experimental Hydrobiological Station". However, in all of abovementioned 3 enterprises the content of this heavy metal varied widely - from 7,14 to $15,96 \mu \mathrm{g} / \mathrm{kg}$ raw weight. In particular, its content varied from 9,92 to $15,96 \mu \mathrm{g} / \mathrm{kg}$ raw weight in fish from the enterprise "Bila Tserkva Experimental Hydrobiological Station" with the middle level of anthropogenic pressure. This index for fish from the enterprise "Nyvka" varied from 7,14 to $13,38 \mu \mathrm{g} / \mathrm{kg}$ raw weight and from 8,96 to $15,04 \mu \mathrm{g} / \mathrm{kg}$ raw weight in fish from enterprise "Training, Research and Production Laboratory of Fish Farming". Accordingly, the Pb content in the organisms of (H2) sampled fish exceed the MAC in all enterprises: by 9,9-16,0 times from the "Bila Tserkva Experimental Hydrobiological Station", by 9,0-15,0 times from the "Training, Research and Production Laboratory of Fish Farming" and by 7,1-13,4 times from "Nyvka". The degree of $\mathrm{Pb}$ concentration increases in the organs and tissues of (H2) hybrid, harvested from 3 above mentioned different enterprises wasn't identical. In turn, this determines the relevance of further research determinants of seasonal changes in the compounds of this heavy metal in ecotopes.

Cobalt. The highest concentration of Co in the organs and tissues of (H1) hybrid silver $x$ bighead carp form that were harvested in the spring of 2017-2018, was observed in fish from the area with the highest level of urbanization - "Nyvka". However, in all of abovementioned 3 enterprises the content of this heavy metal varied widely - from 0,74 to $6,66 \mu \mathrm{g} / \mathrm{kg}$ raw weight. In particular, its content varied from 1,39 to $6,66 \mu \mathrm{g} / \mathrm{kg}$ raw weight in fish from the enterprise "Nyvka" with highest level of anthropogenic pressure. This index for fish from the enterprise "Bila Tserkva Experimental Hydrobiological Station" varied from 0,74 to $1,14 \mu \mathrm{g} / \mathrm{kg}$ raw weight and from 1,2 to 2,04 $\mu \mathrm{g} / \mathrm{kg}$ raw weight in fish from enterprise "Training, Research and Production Laboratory of Fish Farming". Note that according to our investigations, the Co content in the organism of the above-mentioned age group of fish exceed the maximum allowable concentrations (MAC 0,08 $\mathrm{mg} / \mathrm{kg}$ raw weight) in fish from all enterprises: by 9,3-14,3 times from the "Bila Tserkva Experimental Hydrobiological Station", by 15,0-25,0 times from the "Training, Research and Production Laboratory of Fish Farming" and by 4,5-25,6 times from "Nyvka". The degree of Co concentration increases in the organs and tissues of (H1) hybrid, harvested from 3 above mentioned different enterprises wasn't identical. In turn, this determines the relevance of further research determinants of seasonal changes in the compounds of this heavy metal in ecotopes.

The highest concentration of $\mathrm{Co}$ in the organs and tissues of $(\mathrm{H} 1+)$ hybrid silver $x$ bighead carp form that were harvested in the autumn of 2017-2018, was observed in fish from the area with the highest level of urbanization - "Nyvka". However, in all of abovementioned 3 enterprises the content of this heavy metal varied widely - from 0,38 to $2,20 \mu \mathrm{g} / \mathrm{kg}$ raw weight. In particular, its content varied from 0,45 to $2,20 \mu \mathrm{g} / \mathrm{kg}$ raw weight in fish from the enterprise "Nyvka" with highest level of anthropogenic pressure. This index for fish from the enterprise "Bila Tserkva Experimental Hydrobiological Station" varied from 0,51 to $1,28 \mu \mathrm{g} / \mathrm{kg}$ raw weight and from 0,38 to $1,29 \mu \mathrm{g} / \mathrm{kg}$ raw weight in fish from enterprise "Training, Research and Production Laboratory of Fish Farming". Note that according to our investigations, the content of Co in the organism of the above mentioned age group of fish exceed of the MAC in fish from all enterprises: by 5,62-27,5 times ("Nyvka"), by 6,4-16,0 times ("Bila Tserkva Experimental Hydrobiological Station") and by 4,8-16,1 times "Training, Research and Production Laboratory of Fish Farming"). The degree of Co concentration increases in the organs and tissues of (H1+) hybrid, harvested from 3 above mentioned different enterprises wasn't identical. In turn, this determines the relevance of further research determinants of seasonal changes in the compounds of this heavy metal in ecotopes.

The highest concentration of Co in the organs and tissues of (H2) hybrid silver $x$ bighead carp form that were harvested in the spring of 2017-2018, was observed in fish from the area with the middle level of urbanization - "Bila Tserkva Experimental Hydrobiological Station". However, in all of abovementioned 3 enterprises the content of this heavy metal varied widely - from 0,49 to $1,51 \mu \mathrm{g} / \mathrm{kg}$ raw weight. In particular, its content varied from 1,18 to $1,51 \mu \mathrm{g} / \mathrm{kg}$ raw weight in fish from the enterprise "Bila Tserkva Experimental Hydrobiological Station" with the middle level of anthropogenic pressure. This index for fish from the enterprise "Nyvka" varied from 1,09 to 1,49 $\mu \mathrm{g}$ 
/ $\mathrm{kg}$ raw weight and from 0,49 to $0,76 \mu \mathrm{g} / \mathrm{kg}$ raw weight in fish from enterprise "Training, Research and Production Laboratory of Fish Farming". Accordingly, the Co content in the organisms of (H2) sampled fish exceed the MAC in all enterprises: by 14,8-18,9 times from the "Bila Tserkva Experimental Hydrobiological Station", by 6,1-9,5 times from the "Training, Research and Production Laboratory of Fish Farming" and by 13,6-18,6 times from "Nyvka". The degree of Co concentration increases in the organs and tissues of (H2) hybrid, harvested from 3 above mentioned different enterprises wasn't identical. In turn, this determines the relevance of further research determinants of seasonal changes in the compounds of this heavy metal in ecotopes.

Nickel. The highest concentration of $\mathrm{Ni}$ in the organs and tissues of (H1) hybrid silver $x$ bighead carp form that were harvested in the spring of 2017-2018, was observed in fish from the area with the middle level of urbanization - "Bila Tserkva Experimental Hydrobiological Station". However, in all of abovementioned 3 enterprises the content of this heavy metal varied not widely from 2,83 to $4,47 \mu \mathrm{g} / \mathrm{kg}$ raw weight. Particularly, its content varied from 3,57 to $4,09 \mu \mathrm{g} / \mathrm{kg}$ raw weight in fish from the enterprise "Bila Tserkva Experimental Hydrobiological Station" with middle level of anthropogenic pressure. This index for fish from the enterprise "Nyvka" varied from 2,83 to 3,53 $\mu \mathrm{g} / \mathrm{kg}$ raw weight and from 2,96 to 4,47 $\mu \mathrm{g} / \mathrm{kg}$ raw weight in fish from enterprise "Training, Research and Production Laboratory of Fish Farming". Note that according to our investigations, the $\mathrm{Ni}$ content in the organism of the above mentioned age group of fish exceed the maximum allowable concentrations (MAC $0,5 \mathrm{mg} / \mathrm{kg}$ raw weight) in fish from all enterprises: by 7,1-8,2 times ("Bila Tserkva Experimental Hydrobiological Station"), by 5,9-8,9 times ("Training, Research and Production Laboratory of Fish Farming") and by 5,7-7,1 times ("Nyvka"). The degree of $\mathrm{Ni}$ concentration increases in the organs and tissues of (H1) hybrid, harvested from 3 above mentioned different enterprises wasn't identical. In turn, this determines the relevance of further research determinants of seasonal changes in the compounds of this heavy metal in ecotopes.

The highest concentration of $\mathrm{Ni}$ in the organs and tissues of $(\mathrm{H} 1+)$ hybrid silver $x$ bighead carp form that were harvested in the autumn of 2017-2018, was observed in fish from the area with the middle level of urbanization - "Bila Tserkva Experimental Hydrobiological Station". However, in all of abovementioned 3 enterprises the content of this heavy metal varied not widely - from 1,45 to $3,77 \mu \mathrm{g} / \mathrm{kg}$ raw weight. In particular, its content varied from 2,32 to $3,42 \mu \mathrm{g} / \mathrm{kg}$ raw weight in fish from the enterprise "Bila Tserkva Experimental Hydrobiological Station" with the middle level of anthropogenic pressure. This index for fish from the enterprise "Nyvka" varied from 1,66 to 3,77 $\mu \mathrm{g} / \mathrm{kg}$ raw weight and from 1,45 to $2,35 \mu \mathrm{g} / \mathrm{kg}$ raw weight in fish from enterprise "Training, Research and Production Laboratory of Fish Farming”. Note that according to our investigations, the $\mathrm{Ni}$ content in the organism of the above mentioned age group of fish exceed the MAC in fish from all enterprises: by 3,3-7,5 times ("Nyvka"), by 2,9-4,7 times ("Bila Tserkva Experimental Hydrobiological Station") and by 2,32-3,42 times ("Training, Research and Production Laboratory of Fish Farming"). The degree of Ni concentration increases in the organs and tissues of (H1+) hybrid, harvested from 3 above mentioned different enterprises wasn't identical. In turn, this determines the relevance of further research determinants of seasonal changes in the compounds of this heavy metal in ecotopes.

The highest concentration of $\mathrm{Ni}$ in the organs and tissues of (H2) hybrid silver $x$ bighead carp form that were harvested in the spring of 2017-2018, was observed in fish from the area with the middle level of urbanization - "Bila Tserkva Experimental Hydrobiological Station". However, in all of abovementioned 3 enterprises the content of this heavy metal varied gradually - from 2,6 to $4,1 \mu \mathrm{g} / \mathrm{kg}$ raw weight. In particular, its content varied from 3,4 to 4,1 $\mu \mathrm{g} / \mathrm{kg}$ raw weight in fish from the enterprise "Bila Tserkva Experimental Hydrobiological Station" with the middle level of anthropogenic pressure. This index for fish from the enterprise "Nyvka" varied from 2,6 to 3,3 $\mu \mathrm{g} /$ $\mathrm{kg}$ raw weight and from 2,6 to 3,8 $\mu \mathrm{g} / \mathrm{kg}$ raw weight in fish from enterprise "Training, Research and Production Laboratory of Fish Farming". Accordingly, the Ni content in the organisms of (H2) age group of the sampled fish exceed the MAC in all enterprises: by 6,7-8,2 times from the "Bila 
Tserkva Experimental Hydrobiological Station", by 5,3-7,6 times from the "Training, Research and Production Laboratory of Fish Farming" and by 5,1-7,6 times from "Nyvka". The degree of Ni concentration increases in the organs and tissues of (H2) hybrid, harvested from 3 above mentioned enterprises was different. In turn, this determines the relevance of further research determinants of seasonal changes in the compounds of this heavy metal in ecotopes.

Cadmium. The highest $\mathrm{Cd}$ concentration in the organs and tissues of (H1) hybrid silver $x$ bighead carp form that were harvested in the spring of 2017-2018, was observed in fish from the area with the middle level of urbanization - "Bila Tserkva Experimental Hydrobiological Station". However, in all of abovementioned 3 enterprises the content of this heavy metal varied insignificantly - from 2,32 to $4,84 \mu \mathrm{g} / \mathrm{kg}$ raw weight. In particular, its content varied from 3,04 to $3,36 \mu \mathrm{g} / \mathrm{kg}$ raw weight in fish from the enterprise "Bila Tserkva Experimental Hydrobiological Station" with middle level of anthropogenic pressure. This index for fish from the enterprise "Nyvka" varied from 2,32 to 3,66 $\mu \mathrm{g} / \mathrm{kg}$ raw weight and from 2,70 to 4,84 $\mu \mathrm{g} / \mathrm{kg}$ raw weight in fish from enterprise "Training, Research and Production Laboratory of Fish Farming". Note that according to our investigations, the $\mathrm{Cd}$ content in the organism of the above mentioned age group exceed the maximum allowable concentrations (MAC $0,2 \mathrm{mg} / \mathrm{kg}$ raw weight) in fish from all enterprises: by 15,2-16,8 times ("Bila Tserkva Experimental Hydrobiological Station"), by 13,514,2 times ("Training, Research and Production Laboratory of Fish Farming") and by 11,6-18,3 times ("Nyvka"). The degree of Cd concentration increases in the organs and tissues of (H1) hybrid, harvested from 3 above mentioned different enterprises wasn't identical. In turn, this determines the relevance of further research determinants of seasonal changes in the compounds of this heavy metal in ecotopes.

The highest concentration of $\mathrm{Cd}$ in the organs and tissues of $(\mathrm{H} 1+)$ hybrid silver $x$ bighead carp form that were harvested in the autumn of 2017-2018, was observed in fish from the area with the highest level of urbanization - "Nyvka". However, in all of abovementioned 3 enterprises the content of this heavy metal varied not widely - from 1,88 to $4,50 \mu \mathrm{g} / \mathrm{kg}$ raw weight. In particular, its content varied from 2,48 to $4,50 \mu \mathrm{g} / \mathrm{kg}$ raw weight in fish from the enterprise "Nyvka" with the highest level of anthropogenic pressure. This index for fish from the enterprise "Bila Tserkva Experimental Hydrobiological Station" varied from 1,9 to 3,8 $\mu \mathrm{g} / \mathrm{kg}$ raw weight and from 1,88 to $3,78 \mu \mathrm{g} / \mathrm{kg}$ raw weight in fish from enterprise "Training, Research and Production Laboratory of Fish Farming". Note that according to our investigations, the Cd content in the organism of the above mentioned age group exceed the MAC in fish from all enterprises: by 12,4-22,5 times ("Nyvka"), by 9,5-19,0 times ("Bila Tserkva Experimental Hydrobiological Station") and by 9,418,9 times ("Training, Research and Production Laboratory of Fish Farming"). The degree of Cd concentration increases in the organs and tissues of $(\mathrm{H} 1+)$ hybrid, harvested from 3 above mentioned different enterprises was wide-ranging. In turn, this determines the relevance of further research.

The highest $\mathrm{Cd}$ concentration in the organs and tissues of (H2) hybrid silver $x$ bighead carp form that were harvested in the spring of 2017-2018, was observed in fish from the area with the middle level of urbanization - "Bila Tserkva Experimental Hydrobiological Station". However, in all of above-mentioned 3 enterprises the content of this heavy metal varied tenuously - from 1,68 to $3,96 \mu \mathrm{g} / \mathrm{kg}$ raw weight. In particular, its content varied from 2,78 to 3,22 $\mu \mathrm{g} / \mathrm{kg}$ raw weight in fish from the enterprise "Bila Tserkva Experimental Hydrobiological Station" with the middle level of anthropogenic pressure. This index for fish from the enterprise "Nyvka" varied from 1,68 to 3,96 $\mu \mathrm{g}$ $/ \mathrm{kg}$ raw weight and from 2,46 to $3,34 \mu \mathrm{g} / \mathrm{kg}$ raw weight in fish from enterprise "Training, Research and Production Laboratory of Fish Farming". Accordingly, the $\mathrm{Cd}$ content in the organisms of (H2) sampled fish exceed the MAC in all enterprises: by 13,9-16,1 times ("Bila Tserkva Experimental Hydrobiological Station"), by 12,3-16,7 times ("Training, Research and Production Laboratory of Fish Farming") and by 8,4-19,8 times from "Nyvka". The degree of Cd concentration increases in the organs and tissues of $(\mathrm{H} 2)$ hybrid, harvested from 3 above mentioned different enterprises wasn't identical. In turn, this determines the relevance of further research determinants of seasonal changes in the compounds of this heavy metal in ecotopes. 


\section{Conclusions}

Urbanization has an ambivalent effect on aquaculture: it creates an increasing demand for products of this sector of the national economy and sets new challenges to it. In particular, the human-induced impact on ecotopes with each year growing. For example, heavy metals begin to accumulate in them, which pose a potential threat to human health. At the same time, new ways of aquaculture are emerging and provide more efficient control of the final product quality. That's why, special relevance acquires the investigation of the heavy metals content and distribution peculiarities in fish, that is cultivated in the traditional for Ukraine pond-based technology. Pond fish farming in the Kyiv region is not able to provide the required quality of products for the content of heavy metals, which is confirmed by the 3-year study results $(2017-2019)$, carried out on the basis of 3 pond farms from zones with different (high, medium, low) levels of anthropogenic load. Consequently, as a test object we have chosen a hybrid form of bighead carp, as one of the fish species that are in stable demand on the food market of Ukraine. The content of 8 heavy metals $(\mathrm{Zn}$, $\mathrm{Mn}, \mathrm{Fe}, \mathrm{Cu}, \mathrm{Pb}, \mathrm{Co}, \mathrm{Ni}, \mathrm{Cd}$ ) was analysed and made it possible to reveal the excess of their maximum allowable concentrations (MAC) for humans not only in each of the 3 age groups of this fish species, which are in demand on the market, but also in every enterprise. The only exception is $\mathrm{Zn}$, for which the MAC is not exceeded; however, its concentrations confirmed the overall trend. At the same time, for $\mathrm{Zn}$, as well as for $\mathrm{Fe}, \mathrm{Ni}$ and $\mathrm{Cd}$, the stability of the content in fish is traced. The opposite trend is observed in the dynamics of $\mathrm{Mn}, \mathrm{Cu}, \mathrm{Pb}, \mathrm{Co}$, which are characterized by an increasing trend. However, it should be noted that the distribution of all the above-mentioned heavy metals in the body in fish from farms with different levels of a human-induced load and different age cohorts is not identical. In turn, this opens up significant opportunities for both the modernization of pond aquaculture and the marketing of fish products, since the end consumer is interested only in high quality meat. Accordingly, further studies of the characteristics of the distribution of heavy metals in pond aquaculture products are the basis for increasing its economic efficiency.

\section{References}

[1] All Union State Standard 26929-94. Syrye i produkty pishchevyye. Podgotovka prob. Mineralizatsiya dlya opredeleniya soderzhaniya toksichnikh elementov [Raw materials and food products. Sample preparation. Mineralization to determine the content of toxic elements; Interstate Council for Standardization. metrology and certification]. Minsk: Mezhgosudarstvennyy sovet po standartizatsii. metrologii i sertifikatsii (in Russian).

[2] All Union State Standard 30178-96. Syrye i produkty pishchevyye. Atomno-absorbtsionnyy metod opredeleniya toksichnikh elementov [Raw materials and food products. Atomic absorption method for the determination of toxic elements]. Moskva: Standardinform (in Russian).

[3] Askary, Sary A., \& Mohammadi, M. (2012). Lead bioaccumulation and toxicity in tissue of economically fish species from river and marine water. Environmental Contamination Toxicology, 89, 82-85.

[4] Bols, N. C., Brubacher, J. L. \& Ganassin, R. C. (2001). Ecotoxicology and innante immunity in fish. Develompental and Comparative Immunology, 25, 853-873.

[5] Burdina, N. F. (2019). Analysis of features of accumulation and distribution of heavy metals in the body of fish (literature review). Young scientist, 40 (278), 183-185.

[6] Bury, N. R., Walker, P. A. \& Glover, C. N. (2003). Nutritive metal uptake in teleost fish. Journal Experimental Biology, 206(1), 11-23.

[7] Gankevych, B. O., Tretyak, O. M., Kolos, O. M. (2018). Heavy metals in organs and tissues of the paddlefish Polyodon spathula (Walbaum) in fish ponds of the Forest-Steppe and Forest area of Ukraine. Rybogospodars'ka nauka Ukrai'ny, 2, 58-70 (in Ukrainian). 
[8] Gololobova, O. O., Tolstyakova, V. V. (2018). Ecological assessment of the pond ecosystem components, Bobrivka village, Kharkiv district, Kharkiv oblast. Man and environment. Issues of neoecology, 1-2, 81-91 (in Ukrainian).

[9] Golovko, N., Golovko, T., Gelikh, A. (2015). Investigation amino-acid structure of proteins bivalve freshwater Mussels from the family Anodonta of the northern Ukraine. EasternEuropean Journal of Enterprise Technologies, 5/11 (77), 10-16 (in Ukrainian).

[10] Islam, M., Ahmed, M., Raknuzzaman, M., Habibullah-Al-Mamun, M., \& Islam, M.K. (2015).

[11] Heavy metal pollution in surface water and sediment: A preliminary assessment of an urban river in a developing country. Ecological Indicators, 48, 282-291.

[12] Lytvynova, T. H., Melnyk, A. P. \& Stetsiuk, Z. A. (2005). Faktory nakopychennia vazhkykh metaliv v ekosystemi Dniprovskykh vodoskhovyshch [Factors of accumulation of heavy metals in the ecosystem of the Dnipro reservoirs]. Rybne hospodarstvo, 64, 131-143 (in Ukrainian).

[13] Melnyk, A.F., Vlasova, N.M. \& Zakharchenko I.L. (2011). Rozpodil ta nakopychennia vazhkykh metaliv $\mathrm{v}$ orhanakh i tkanynakh promyslovykh vydiv ryb Kakhovskoho vodoskhovyshcha [Distribution and accumulation of heavy metals in organs and tissues of industrial fish species of the Kakhovka reservoir]. Rybohospodarska nauka Ukrainy, 1, 74-80 (in Ukrainian).

[14] Melnyk, A. F., Vlasova, N. M. \& Zakharchenko I. L. (2011). Rozpodil ta nakopychennia vazhkykh metaliv $\mathrm{v}$ orhanakh i tkanynakh promyslovykh vydiv ryb Kakhovskoho vodoskhovyshcha [Distribution and accumulation of heavy metals in organs and tissues of industrial fish species of the Kakhovka reservoir]. Rybohospodarska nauka Ukrainy, 1, 74-80 (in Ukrainian).

[15] Myslyva, T. M. (2016). Vazhki metaly i mikroelementy $\mathrm{v}$ orhanakh i tkanynakh predstavnykiv ikhtiofauny malykh richok Zhytomyrskoho Polissia [Heavy metals and trace elements in the organs and tissues of small rivers ichthyofauna from the Zhytomyr Polissya]. Visnyk ZhNAEU, 1(53), 22-34 (in Ukrainian).

[16] Nasrabadi, T. (2015). An index approach to metallic pollution in riverwaters. Int. J. Environ. Res. 9(1), 385-394.

[17] Kurbatova I. M. (2019). The role of xenobiotics in the violation of the ecological balance of aquatic ecosystems under anthropogenic load: author. dis. ... Dr. Biol. Sciences: 03.00.16, Chernivtsi. nat. Univ. Yuriy Fedkovych (Chernivtsi).

[18] Sytnyk, Yu. M. (2012). Vmist vazhkykh metaliv v orhanakh ta tkanynakh ryby deiakykh stavkiv richky Nyvka (Kyiv) [Content of heavy metals in fish organs and tissues of some ponds of the Nyvka River (Kyiv). Rybohospodarska nauka Ukrainy, 2, 106-110 (in Ukrainian).

[19] Sytnyk Yu. M., Shevchenko P.G., Zabytivsky Yu. M. (2006). Toxicological aspects of eel death in Lake Chorne Velyke of Shatsk National Nature Park (review). Scientific herald: Collection of scientific and technical works. National Forestry University of Ukraine, 16.5, 558.

[20] Tsvetkova, N.M., Pakhomov, O.Y., Serdyuk, S.M., Yakyba, M.S. (2016). Biologichne riznomanittja Ukrajiny. Dnipropetrovs'ka oblast'. Grunty. Metaly u gruntah [Biological diversity of Ukraine. The Dnipropetrovsk region. Soils. Metalls in the soils]. Lira, Dnipropetrovsk (in Ukrainian). 